\title{
RESOLVING RELIGIOUS CONFLICTS THROUGH EXPANDING INTER-RELIGIOUS COMMUNICATION: Issues and Challenges
}

\section{Peter Suwarno}

Associate professor at Arizona State University

الملخص

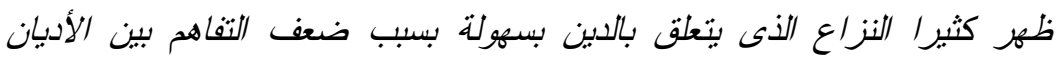

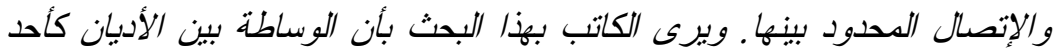

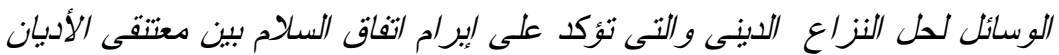

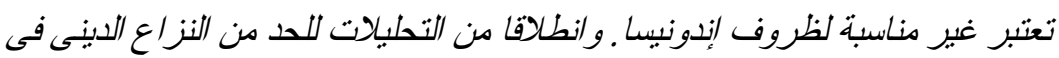

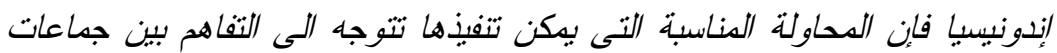

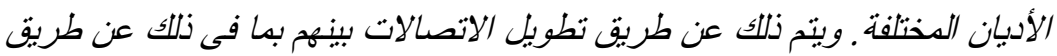

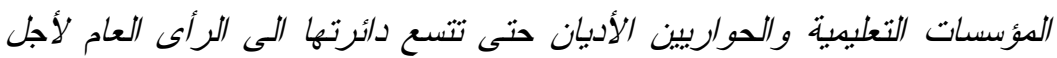
تطوير عرف بناية سلام.

\section{Abstrak}

Konflik yang terkait dengan isu keagamaan sering timbul dengan sangat mudah. Tanpa menafikan hadirnya oknum provokator, konflik ini biasanya muncul karena rendabnya sikap saling pengertian dan terbatasnya komunikasi antar agama. Dalam artikel ini, penulis berpandangan bahwa mediasi-sebagai salah satu jalan keluar yang popular untuk mengatasi konflik keagamaan, yang lebib menekankan terwujudnya kesepakatan damai antar pemeluk agama-kurang cocok untuk kondisi di Indonesia. Berdasarkan analisis atas usaba untuk. 
resolusi konflik keagamaan di Indonesia, upaya yang lebih cocok untuk dilakukan adalab yang mengarah pada upaya saling memahami antar kelompok agama yang berbeda-beda. Hal itu dapat diusabakan melalui peningkatan komunikasi antar pemeluk agama, termasuk melalui jalur pendidikan formal, dialog antar agama, bingga memperluas ruang publik. untuk pengembangan tradisi peace building.

Keywords: religion, conflict, communication, dialogue, peace building.

\section{A. Introduction}

As the fourth most populous nation in the world with great ethnic and religious diversity, Indonesia is going through a complex process of reform, decentralization, and democratization that polarizes the society and, thus, creates multifaceted conflicts. Among these difficultto-solve conflicts in recent years, perhaps the conflicts labeled "religious" are the most atrocious and difficult ones to deal with. Although the economy and politics play very important roles in constructing these conflicts, the recent increase in religious conservatism in Indonesia, ${ }^{1}$ has augmented the potential for conflicts attributable to religious differences. ${ }^{2}$

Religion-related conflicts can easily erupt when people believe that their religious doctrines, teachings, tradition, and values, which they consider sacred, are under threat. Although some religious conflicts are incited by provocateurs and certain political elites, ${ }^{3}$ conflicts can also occur when different religious groups lack mutual understanding because of limited inter-religious communication. The increasingly

${ }^{1}$ G. Fealy, Islamic Radicalism in Indonesia: The Faltering Revival?, Singapore: Institute of Southeast Asian Studies, 2004, pp. 104-121; R. W. Hefner, "Global violence and Indonesian Muslim Politics”, American Anthropologist, V.104, No: 3, 2002, pp. 754165.

${ }^{2}$ Based on excerpts from Asia Society panel discussion, New York: October 24, 2000 presented by Sydney Jones, Executive Director, Asia Division, and Human Rights Watch.

${ }^{3}$ It has been widely suspected that political elites play important roles in inciting religious conflicts in Indonesia. For an example of possible involvement of special military personnel in Ambon conflicts, see Jakarta Post's Thursday, May 16, 2002 news on "Police, Army trade blame over Ambon shooting" Thursday, May 16, 2002 
exclusive religious rhetoric that emphasizes purification instead of compassion can also directly or indirectly convince the followers to antagonize the ills seen in other religions. This kind of rhetoric can lead to the portrayal of other groups as infidels that need to be converted or, worse, as enemies that need to be dominated or eliminated. Consequently, escalating religious conflicts in Indonesia will endanger religious freedom and inter-religious relationship that can extend beyond Indonesia and affect other countries.

There are many different ways and strategies of resolving religious conflicts, each with its own successes and failures. While violent and coercive ways of resolving conflicts in a country with an authoritarian regime are often practiced with limited success, mediation constitutes one of the most widely accepted conflict resolution approaches in the modern world. In this presentation, I will discuss the issues and challenges of religious conflict resolution in Indonesia and suggest that, instead of focusing on mediation which emphasizes achieving agreements, fostering inter-religious communication is more urgently needed in a country where most religious groups are not used to rational and direct negotiation. To expand the practice of interreligious communication, I will discuss the limits of inter-religious dialogue, and propose that Indonesians need more public space as a basic necessity that enables them to communicate and build peace. I will base my arguments mostly on my experience, interviews, and observations during the ongoing conflict resolution exchange project between Arizona State University and four Indonesian institutions. ${ }^{4}$

\section{B. Communication as Conflict Resolution}

Traditionally, some conflicting groups in Indonesia have been successful in practicing informal conflict resolution methods, such as silahturahmi (a meeting to strengthen or renew family relationship),

${ }^{4}$ The exchange project on conflict resolution is funded by the Bureau of Educational and Cultural Affairs, US Department of State (July 2003-June 2006), which involves State Institute of Islamic Studies (IAIN) Raden Intan, Bandar Lampung; IAIN Walisongo, Semarang; IAIN Mataram, Lombok; and Satya Wacana Christian University (UKSW), Salatiga. Each institution has established a mediation center with various formal and informal conflict resolution activities in their regions. 
musyawarah (deliberation to achieve a consensus), and islah (informal reconciliation to achieve peaceful relationship). However, these traditional methods that seek to confirm agreements or to attain consensus only apply to easy-to-solve conflicts where all conflicting parties have high interest in building a good relationship. ${ }^{5}$ Recent religious conflicts in Indonesia are far too complex to be dealt with using these methods, and require alternative approaches.

Mediation is a popular modern approach that has been applied in many different parts of the world to deal with hard-to-solve conflicts including in Indonesia. The ideal modern mediation theories stipulate that if voluntary, collaborative negotiation between the conflicting parties cannot take place, conflict resolution requires the intervention of an experienced and neutral third party to facilitate peaceful negotiation in order to achieve a long term, acceptable resolution. ${ }^{6}$

Various versions of mediation steps have been employed with different degrees of success by the four Indonesian institutions involved in the conflict resolution project that I supervise. Typically, the ability to reach a final agreement is an indication of the success of mediation. In our projects thus far, final agreements are successfully achieved in mediation projects that deal with concrete, rational matters and regulations, such as labor and land disputes, where bargaining and negotiation can be directed toward a compromise. ${ }^{7}$ However, when it comes to interethnic, intercultural, and, especially, inter-religious conflicts, the mediation activities are far away from reaching an acceptable, long-term resolution. This is true because the agreement itself cannot create a lasting, peaceful inter-religious relationship. For example, the mediation initiated by the Indonesian government to deal with religious conflicts in Ambon and Poso, resulting in Malino I and Malino II agreements respectively, was partly based on these mediation

${ }^{5}$ P. Suwarno, Mapping Multi-faceted Conflicts in Indonesia: The Challenges of Empowerment and Neutrality in Mediation, presented at the 3rd Annual Convention of Asia Scholar, Singapore, August 11-13, 2003.

${ }^{6}$ C. W. Moore, The Mediation Process: Practical Guide for Resolving Conflicts (San Francisco: Jossey-Bass, 1996).

${ }^{7}$ Fisher, R. \& Ury, W., Getting to Yes: Negotiating Agreement without Giving in (New York: Penguin, 1991). 
principles. However, these agreements are considered a failure, ${ }^{8}$ because avoidance, coercion, and violent clashes between the conflicting parties still occur.

Employing modern principles of mediation to resolve conflicts is challenging in Indonesia. First, the conflicting parties have to be convinced to negotiate and that they need a mediator if they cannot communicate and negotiate directly. Second, it is difficult and timeconsuming to prepare and find neutral mediators that have knowledge, experience, and skills to train the disputants for a peaceful negotiation and encourage them to communicate openly, develop trust, and tolerate differences. Finally, even if the disputing parties agree to use mediation, most of the time at least one party will still feel incapable, intimidated, apprehensive, angry, or even traumatized and, thus, cannot actively participate in a peaceful negotiation to reach an agreement.

These difficult tasks, coupled with my own experience in dealing with various conflict resolution projects in Indonesia, have led me to conclude that reaching final agreements should not be the ultimate goal of conflict resolution activities. This conclusion is supported by several facts: First, engaging the conflicting parties in a peaceful negotiation, which is the requisite for reaching a long term agreement, ${ }^{9}$ already constitutes the greatest challenge in Indonesian conflict resolution. Second, an agreement-oriented conflict resolution process usually results in a hasty, not-well-thought-out agreement or resolution that does not reflect long term mutual understanding between the conflicting people who have to live side-by-side. Finally, in many cases, even though the representatives of the conflicting parties have reached an agreement, the party members themselves do not abide by the agreement, especially when law enforcement is minimal at best. The latter situation results in continuous clashes between the conflicting

${ }^{8}$ See, for example, articles discussing the flaws and failures of Malino accords, such as: Syamsul Alam Agus, "Peace for Poso: Highlighting the State's Role May Help Stop the Poso Conflict", Inside Indonesia, October-December, 2001, and Lorraine V. Aragon, "Waiting for Peace in Poso: Why Has this Muslim-Christian Conflict Continued for Three Years?”, Inside Indonesia, April-June, 2002.

${ }^{9}$ C.W. Moore, The Mediation Process: Practical Guide for Resolving Conflicts (San Francisco: Jossey-Bass, 1996). 
parties, as exemplified by the previously mentioned Malino I and Malino II accords.

The above facts convince me that communication should become the goal of conflict resolution activities in Indonesia. Communication, which is the most challenging step in most mediation processes, is not only the tool for achieving agreements but, more importantly, it is the key to a long-term peacemaking effort. Only when this step is achieved, the disputants can deal with issues and challenges of the conflicts throughout their interaction even after the formal agreements have been reached. This is in line with the proposals of communication scholars who have developed communication perspectives in conflict resolution and mediation theories. ${ }^{10}$ They believe that communication is not just a medium of exchanging and sharing messages; it is the environment where human action and interaction takes place. In fact, conflicts are constructed within the interaction among people or groups, such that to resolve these conflicts, people must examine the nature of the interaction and improve the communication patterns. ${ }^{11}$

Cross cultural and inter-religious tensions begin when miscommunication and mutual lack of knowledge cause misunderstanding that prevent us from appreciating differences. Communication is a crucial conflict prevention and resolution process, because continuous communication can help build trust, minimize misunderstandings, eliminate suspicion and hatred as well as create a reciprocal knowledge. ${ }^{12}$

To be a successful conflict resolution process, communication must be open, in that all parties involved must be honest about their thoughts and feelings in order to build trust and respect for each other. Open communication also means that all participating groups have

${ }^{10}$ S.W. Littlejohn \& K. Domenici, Engaging Communication in Conflict: Systemic Practice (Thousand Oaks, CA: Sage Publication, 2001); J.P. Folger \& T.S. Jones (Eds.), New Direction in Mediation: Communication Research and Perspectives (Thousand Oaks, CA: Sage Publication, 1994).

${ }^{11}$ Ibid.

${ }^{12}$ This is in line with the summary of the report of International Conference on Inter-religious Dialogue, Tashkent, Uzbekistan 14-16 September 2000. 
the right and willingness to express themselves and listen to others. ${ }^{13}$ Therefore, the most important component of resolving conflict is engaging the disputing parties in continuous, peaceful, open communication.

In Indonesia, the difficulty in implementing communication openness is making it part of the culture of Indonesian religious groups. Similar to Asian culture in general, Indonesian culture is characterized by paternalistic, hierarchical and, in some groups, feudal system where communication process is dominated by a select few, differing opinions and criticism is often perceived as a personal attack, and face-saving is very important for maintaining harmonious relations. ${ }^{14}$ Therefore, in a conflict resolution process which requires serious negotiation and bargaining, not many disputants can actively participate in a fair negotiation and open communication. Instead, they practice avoidance and, in some cases, coercion and violence. To create peace, therefore, is an overwhelming task, because it will have to include educating and training community members and leaders in various communication skills such as cross-cultural communication, active listening, peaceful negotiation as well as controlling anger and emotion.

Another challenge of open communication as the major part of conflict resolution is that there is not always balance of power among the participants. Usually, to whatever extent, some participants can exert more power than the other to achieve their goals. This is especially true in communities where certain groups tend to be politically, religiously, economically, or socially more dominant than the others. Controlling the influence of powerful participants is difficult because it is not always easy to become aware of the display or use of power in communication. Without strong awareness of such existence and the willingness to control it, the imbalance of communication will intimidate certain groups of participants and limit the fairness of the peacemaking process.

\footnotetext{
${ }^{13}$ S.W. Littlejohn \& K. Domenici, Engaging Communication.

${ }^{14}$ S. Ting-Toomey \& Oetzel J.G., Managing Intercultural Conflict Effectively (London: Sage Publication Inc., 2001).
} 


\section{Dialogue as Inter-religious Conflict Prevention and Resolution}

Inter-religious communication in Indonesia typically takes place in the form of a formal dialogue as evident in the establishment of many interfaith dialogue centers in the country. Dialogue is a constructive and peaceful conversation that provides an environment for each party to express themselves and learn from others, making it possible to explore differences and common grounds. Inter-religious dialogue requires, among others, that the participants are temperate, have high tolerant attitude, and are willing to engage in exchanges of views and ideas with other people from completely different backgrounds.

Without disregarding the significant roles of inter-religious dialogue in creating better inter-religious relationship, I would like argue that a large number of religious Indonesians are not progressive enough to meet the above requirements. This makes it difficult to implement dialogues in this country where there is a significant increase of religious conservatism. This is true especially when it is necessary for dialogue participants to be able to live "in the tension between standing their grounds and being profoundly open" to others' opposing views. That is, participants in a dialogue must be free and able to express their opinions, feelings, values, and interests, but they must also be willing to listen openly to those of others. ${ }^{15}$

There are other factors that make it challenging to employ a dialogue as peacemaking strategy; some of which I will describe briefly. Perhaps the first and most obvious difficulty lays in the reluctance and unwillingness of certain religious groups to engage in any communication with other religious groups. Some religious groups are reluctant to participate in inter-religious communication because of fear of outside influence. These groups that usually lack knowledge about and trust in other groups have been disheartened by religious leaders from having any serious interaction with other religious groups. ${ }^{16}$

${ }^{15}$ S.W. Littlejohn \& K. Domenici, Engaging Communication, p. 47.

${ }^{16}$ For example, the edicts (fatwa) recently issued by the Indonesian Council of Ulemas (MUI) prohibiting Ahmadiyah sect of Islam, was widely viewed as reflecting conservative and exclusive moves of Indonesian religious leaders. Many religious leaders blame these edicts for violence against Ahmadiyah group in Bogor, West Java. 
There are also religious radical groups who reject any dialogue with any moderate and liberal groups that they consider their enemies. Radical groups that tend to be emotional in expressing their opinions would have a hard time understanding and following a clear set of standards for peaceful dialogue, including the requirements that the participants are engaged in peaceful, non-violent, rational communication. ${ }^{17}$

Second, the ideal but unrealistic dialogue is one that seeks to discover only points of similarities in the different religions. Such an attempt does not facilitate true peaceful dialogue, because it only shows that the differing parties are not capable of "standing their grounds while being profoundly open". ${ }^{18}$ Without discounting the fact that there are similarities in various religions that can help build bridges among different groups, the main challenge in Indonesia is not how to make religions look similar so that we can enjoy the comfort of living in superficial homogeneity, but how the followers of all religions can accept differences and be able to live in this diversity peacefully.

The third difficulty occurs when the religious disputing parties in a negotiation have emotional and psychological problems, since religious issues are closely related to emotional matters. These parties range from some revengeful groups who feel they have been wronged and cannot control their anger to those who suffer from traumas. This happens among conflicting groups who have suffered fatalities, such as those in Poso and Ambon. A dialogue cannot take place until these psychological problems are dealt with through training and consultation in anger management, forgiveness, and trauma healings.

Finally, inter-religious dialogues in Indonesia have been criticized of involving only few educated and liberal leaders and of neglecting the people at the grassroots level. ${ }^{19}$ The interfaith dialogues often

${ }^{17}$ Islam Liberal Network (JIL) a progressive group which emphasizes rational dialogue often collides with radical and conservatives groups that reject peaceful and rational dialogue. See for example, a dialogue between JIL and Muslim Community Forum of Utan Kayu in JIL, 10/24/05: http://islamlib.com/id/ index.php?page $=$ article\&id $=912$.

${ }^{18}$ S.W. Littlejohn \& K. Domenici, Engaging Communication.

${ }^{19}$ For an example of such criticism, see: Ulil Abshar-Abdalla, "Beberapa Kendala Praktis Dialog Antar-agama”, Kompas, Saturday, Agustus 5, 2000 
involve religious leaders who convey their liberal views of religious tolerance in the interfaith forum but do not communicate this view in their interaction with their groups at the grassroots level. On the other hand, there are religious teachers and preachers who actively speak in various local forums and who have vital roles in shaping the attitude and world views of the people at the grassroots level, but do not have any interest in any inter-religious dialogue or in learning about other religions.

Some of the requirements for a dialogue described above are not easy to achieve in Indonesia, due to the diversity of various religious groups and their varying degree of readiness to participate in a dialogue. Since a successful dialogue on important and serious issues should involve everybody, there have been proposals on models of Indonesian inter-religious dialogues that can be joined by people from different walks of life. For example, Smock suggested dialogues at different levels and with different goals and different formats. His suggestion ranges from dialogue among high-level religious leaders to grassroots dialogues across religious divisions to encourage cross-community communication and peacemaking. ${ }^{20}$ In Indonesia, Interfidei ${ }^{21}$ proposed three different kinds of dialogues: "life dialogue" which deals with conversation on common concerns regarding daily life, "action dialogue" which is directed toward removing barriers for living sideby-side, and "theological dialogue" which is joined mostly by scholar and religious leaders to discuss theological issues. These categores of dialogue may be in line with Eck's suggestion of six different types of dialogue: parliamentary dialogue, institutional dialogue, theological dialogue, theological dialogue, dialogue in community, dialogue of life, spiritual dialogue and inner dialogue. ${ }^{22}$

While the above models differ in terms of how dialogue should be carried out, they are limited to the use of verbal communication which is the skill that not very many Indonesian people have and/or

${ }^{20}$ David R. Smock, Interfaith Dialogue and Peacebuilding (Herndon, VA: United States Institute of Peace Press, 2002).

${ }^{21}$ An interfaith organization headquartered in Yogyakarta.

${ }^{22}$ D. L. Eck, “What Do We Mean by 'Dialogue'?” (Current Dialogue, December 11, 1986). 
are comfortable with. Dialogue is only one kind of communication as a conflict resolution process and, according to Gopin, has its limits. ${ }^{23}$ By itself dialogue cannot be considered peacemaking. Religious conflicts are complex phenomena, in that they deal with various aspects of human beliefs that cannot only be articulated through verbal communication, but also with feeling and emotion that, in Indonesia, are usually expressed indirectly or symbolically. Relying only on verbal and formal dialogues, conflicting people can easily miss cues, symbols and subtle information that are very significant and have to be carefully interpreted and responded for a successful peacemaking. Therefore, it is important to engage diverse religious groups or disputants in various forms of communication in different places, activities and events to involve all community members regardless of their status and skills in maintaining or creating peace. This is in line with an expanded version of dialogue that Eck called: dialogue in community and dialogue of life, ${ }^{24}$ inclusive dialogue that encompass unstructured interaction among people of different backgrounds.

\section{Expanding Public Space for Peace Building}

As mentioned above, modern conflict resolution theories which tend to rely on rational procedures and negotiation usually cannot be applied to religious conflicts because they do not always rely on rational thinking. As part of the rational procedure, conflict resolution theories encourage scholars and practitioners to analyze conflicts by examining the causes in order to come up with resolution. ${ }^{25}$ In the case of religious conflicts, scholars and practitioners of conflict resolution examine the causes of conflicts in terms of what is wrong in religions and the religious people that ignite the conflicts. The problem with this view is its tendency to look at the negative side of religions by concentrating at the potentials of religions in creating conflicts, while overlooking

\footnotetext{
${ }^{23}$ M. Gopin, Between Eden and Armageddon: The Future of World Religions, Violence, and Peacemaking (New York: Oxford University Press, 2000), p. 5.

${ }^{24}$ D. L. Eck, "What Do...".

${ }^{25}$ R. Fisher \& W. Ury, Getting to Yes: Negotiating Agreement without Giving in (New York: Penguin, 1991).
} 
the capacities of religions and humans in peacemaking. ${ }^{26}$

In order to maximize the positive potentials of religions, we must examine and expand all aspects in religions and their followers that can help promote peacemaking activities. As discussed above, interreligious dialogue is only one of those positive aspects in religions where people from different religious groups can share their knowledge and experiences for better inter-religious relationship. However, emphasizing verbal skills, a formal dialogue described above has its limits. Perhaps, communication that is open to all should be developed to embrace diverse potentials of all religions' members to encourage their participation in peace-building efforts. To be more inclusive, this open communication must cover a wide range of human interaction in different settings that can be implemented in the form of activities or events open to anyone from any background. For this purpose, people need a public space.

Habermas termed public space as "public sphere" which he defined as a "virtual or imaginary community which does not exist in any identifiable space" for people to gather as a public expressing their needs, views, and concerns, thus becoming a source of public opinions shaping and changing the public policy in a democratic society. ${ }^{27}$ To eliminate the impression that only certain groups of people can actively participate in it, I am referring to public space to be any meeting place, forum or media where anyone can communicate verbally or symbolically, directly or indirectly. In a public space, although people can display their identities, they should be treated relatively equal regardless of their religions and social status in their private space. Although there is a general rule of laws and norms that must be followed by everyone, there is no set of specific rules of interaction such as what happen in the market or on city streets. Often, people do not realize that public space is a place where they are exposed to different kinds of individuals. Through a public space, people communicate their experience and ideas as part of the on going process

${ }^{26}$ M. Gopin, Between Eden and Armageddon.

${ }^{27} \mathrm{~J}$. Habermas, The Structural Transformation of the Public Sphere: An Inquiry into Category of Bourgeois Society, translated by T. Burger and F. Lawrence (Cambridge, MA: MIT Press, 1991). 
of constructing our standards, world views, and perceived reality.

Gopin's work in helping create peace in the Middle East shows that public spaces play very important roles in mending relationship of the conflicting groups, when the formal dialogue fails. The public spaces which are informal, unstructured interaction frequently become the "psychological bridge" for the conflicting groups. While each individual must restrain himself or herself from being overly sectarian, each person can find a comfort of not having to conform to private or sectarian rules and norms, thus allowing them to interact without apprehension. ${ }^{28}$

The number and amount of public spaces determines the number and amount of inter-religious or interethnic communication of at the grassroots levels. However, public space may be decreasing in line with increasing exclusiveness and religious purification, where communities are divided into classes and sections. This is true in Indonesia where there are not only spaces for the haves and for the have nots, but also spaces for the religious and non-religious, as well as the spaces for the radicals and the liberals. Very often people are unaware that politically, economically or religiously dominant groups have turned public spaces into sectarian and private space, decreasing the amount and number of public space, which is crucial for informal dialogues and open communication where people from diverse backgrounds meet and interact while participating in peacemaking. If formal dialogues are dominated by the highly educated, scholarly, broad-minded participants, the people at the grassroots level can only participate in a form of informal communication in daily life through public spaces. This may include the markets, the streets, the soccer fields, the parks, the public meeting rooms, and public schools, government institutions or buildings as well as media and public forums. Furthermore, public spaces can be in a form of activities, such as sports, picnics, and cooperatives. For these public spaces to be joined by diverse groups without any intimidation or apprehension, they must be maintained so that they remain public and not become sectarian, because to build peace in a

${ }^{28}$ M. Gopin, Holy War, Holy Peace: How Religion Can Bring Peace to the Middle East (New York: Oxford University Press, 2002). 
diverse communities like Indonesia, people need to be able to balance between participating in private and in public space.

\section{E. Enhancing Inter-religious Communciation through Education}

The Indonesian people's ability and willingness to participate in public space and in open communication requires formal as well as informal education which is the basic, long-term activity that could become the foundation for peaceful inter-religious dialogue and open communication in public spaces. Education of open communication and cross-cultural communication should also be part of the school curriculum, in addition to education of pluralism and tolerance. Religious education, which is sectarian, must also be inclusivecomparative, instead of literalist-exclusive. It must emphasize religious compassion and put less emphasis on religious purification. While religious purification is similar to literalist-exclusive education, religious compassion does not only encourage the learning of pluralism and tolerance, but, more importantly, advocates compassion in general. Religious classes should educate children to be loving, caring, as well as concerned about the well-being and welfare of other people (religious compassion), rather than to have the skills, knowledge, and discipline in practicing religious rituals (religious purification). This is in line with, for example, Rakhmat's suggestion that akblaq (moral) is more important than figh (Islamic jurisprudence). ${ }^{29}$ Such education will not only improve inter-religious communication, but also help expand the participation in public space which is crucial for peacemaking.

\section{F. Concluding Remark}

Continuing religious conservatism and exclusiveness in Indonesia may lead to long term tension and conflicts among different religious groups. To prevent and resolve this situation, government, community, and religious leaders should not focus only on seeking resolution and agreement through conflict resolution and formal mediation. Instead, they should concentrate on helping the conflicting religious groups to engage in continuous, peaceful, and open communication and dialogues

${ }^{29}$ J. Rakhmat, Dabulukan Akblak di Atas Fikih (Bandung: Mizan, 2005). 
at different levels in various forms. Resolving conflict in Indonesia is a very challenging task, a campaign for open communication helps each conflicting group understand the other as well as eliminates fear and suspicions, thus giving hope of enabling them to live side by side peacefully.

Successful inter-religious dialogues that have been practiced in different parts of Indonesia should be continued and expanded. However, there should be more awareness that dialogue requires verbal skills, knowledge, understanding and openness that not many Indonesians at the grassroots levels can participate. By itself dialogue cannot become a peacemaking process, and thus needs to be expanded to include open communication in a public space. The expansion of public space will encourage better participation of societal members and a fair process of the construction of opinions, world views and reality. To expand active participation in a public space, there needs to be a religious education that deals with pluralism or even tolerance ${ }^{30}$ as well as, more importantly, with communication openness and religious compassion.

Conflicts are part of human life. As long as people interact with other people, there will always be tension and conflicts to a certain degree. ${ }^{31}$ The positive way to look at a conflict is to take it as an opportunity to communicate and create an understanding with other people and be able to live side by side while respecting the differences.

${ }^{30}$ F. Magnis-Suseno, "Education for Tolerance among Religious Communities: The Case of Indonesia", in S.F. Alatas, L.T. Ghee \& K. Kuroda (Eds.), Asian Interfaith Dialogue: Perspectives on Religio, Education and Social Cohesion (Singapore: Rima, 2001), pp.160-170.

${ }^{31}$ G. Tillett, Resolving Conflict: A Practical Approach (New York: Oxford University Press, 1991). 


\section{BIBLIOGRAPHY}

Bush, R.A.B., \& Folger, J.P., The Promise of Mediation: Responding to a Conflict through Empowerment and Recognition (San Francisco: JosseyBass, 1994).

Eck, D. L., "What Do We Mean by 'Dialogue'?" (Current Dialogue, December 11, 1986).

Fealy, G., Islamic Radicalism in Indonesia: The Faltering Revival? (Singapore: Institute of Southeast Asian Studies, 2004).

Fisher, R. \& Ury, W., Getting to Yes: Negotiating Agreement without Giving in (New York: Penguin, 1991).

Folger, J.P. \& Jones, T.S. (Eds.), New Direction in Mediation: Communication Research and Perspectives (Thousand Oaks, CA: Sage Publication, 1994).

Gopin, M., Between Eden and Armageddon: The Future of World Religions, Violence, and Peacemaking (New York: Oxford University Press, 2000).

-, M., Holy War, Holy Peace: How Religion Can Bring Peace to the Middle East (New York: Oxford University Press, 2002).

-, Healing the Heart of Conflict: 8 Crucial Steps to Making Peace with Yourself and Others (Emmaus, Pennsylvania: Rodale, 2004).

Habermas, J., The Structural Transformation of the Public Sphere: An Inquiry into Category of Bourgeois Society, translated by T. Burger and F. Lawrence (Cambridge, MA: MIT Press, 1991).

Hefner, R. W., "Global Violence and Indonesian Muslim Politics", American Anthropologist, V.104, No: 3, 2002.

Littlejohn, S.W. \& Domenici, K., Engaging Communication in Conflict: Systemic Practice (Thousand Oaks, CA: Sage Publication, 2001).

Magnis-Suseno, F., "Education for Tolerance among Religious Communities: The Case of Indonesia", in S.F. Alatas, L.T. Ghee \& K. Kuroda (Eds.), Asian Interfaith Dialogue: Perspectives on Religio, Education and Social Cohesion (Singapore: Rima, 2001). 
Moore, C.W., The Mediation Process: Practical Guide for Resolving Conflicts (San Francisco: Jossey-Bass, 1996).

Rakhmat, J., Dabulukan Akblak di Atas Fikih (Bandung: Mizan, 2005).

Smock, David R., Interfaith Dialogue and Peacebuilding (Herndon, VA: United States Institute of Peace Press, 2002).

Suwarno, P., Mapping Multi-faceted Conflicts in Indonesia: The Challenges of Empowerment and Neutrality in Mediation, presented at the 3rd Annual Convention of Asia Scholar, Singapore, August 11-13, 2003.

Tillett, G., Resolving Conflict: A Practical Approach (New York: Oxford University Press, 1991).

Ting-Toomey, S. \& Oetzel J.G., Managing Intercultural Conflict Effectively (London: Sage Publication Inc., 2001). 
